09

\title{
AN EMPIRICAL ANALYSIS ON SUSTAINABILITY AND ECONOMIC GROWTH - PERSPECTIVE OF DIFFERENT INDIAN STATES
}

\author{
Geetanjali Singh ${ }^{1}$ and Nistha Pattar ${ }^{2}$ \\ ${ }^{1}$ Assistant Professor, ${ }^{2}$ Masters in Economics, \\ Department of Economics, Mehr Chand Mahajan DAV College, Chandigarh, India \\ Email: geetanjalis52@gmail.com, nisthapattar6@gmail.com
}

How to cite this paper:

Singh, Geetanjali and Pattar, Nistha (2021) An Empirical Analysis on Sustainability and Economic Growth Perspective of Different Indian States, Journal of Global Resources, Vol. 07 (02)

DOI:

10.46587/JGR.2021.v07i02.009

Received: 05 March 2021

Reviewed: 25 April 2021

Revised: 21 May 2021

Final Accepted: 25 May 2021

OPEN O ACCESS

Freely available Online www.isdesr.org

\begin{abstract}
The world is witnessing massive changes, which clearly highlight the fact that for long-term development and growth, the approach of sustainability is the only viable option. The present research paper aims at highlighting the relationship between the gross state domestic product (GSDP) of various Indian states and its relationship with the long-term vision of sustainability that these states hold. The paper aims at portraying that sustainable development and not shortsighted materialistic growth holds the key to ultimate well-being of the people. Our Forests constitute natures wealth and therefore are taken as a criteria and parameter to measure the sustainability quotient of the various Indian states. The central government and also various state governments have come up with various programmes and schemes for increasing the forest cover, but the results of percentage increase in forest cover holds the key to show as to whether these schemes and programmes have been fruitful in reality or not. Through various graphs, ratios and other statistical tools and techniques, we show whether or not the states have the vision and foresight towards a more environmentally inclusive development. It is clearly visible that only few states, namely, Andhra Pradesh, Himachal Pradesh and Karnataka have shown improvement that can be categorized as satisfactory. Other states have followed only a short-term and narrow approach to development, not realizing the fact that sustainability ultimately holds the key and is the future of mankind. It is high time that we realize the need of the hour and take immediate steps in the right direction for long term prosperity of the states and nation as a whole.
\end{abstract}

Keywords: Economic development, Economic Growth, Forest Cover, Gross State Domestic Product, Sustainability. 


\section{Introduction}

For a long period of time economic growth and economic development had been used as synonyms terms. But the difference between the two is now well accepted. While economic growth caters to quantitative perspectives like GDP, per capita income etc., economic development is a broader and more holistic concept. Economists over the years have developed the concept beautifully well and it is still under the process of evolution. the concept is wide and dynamic enough to cater to and subsume all additions around the world. The concept of Sustainable Development gained ground in 1987 when the Brundtland Report was published. It laid down the foundation stone for a new approach of how world's development would henceforth be valued.

The concept of sustainability has now become a reality and the only source of human beings' long term healthy survival. Today's uncertain times have made it certain that human beings cannot be the master of the planet and the best option is to remain in harmony with nature, to develop by enriching the world rather than recklessly destroying it. The sustainability aspect opens the eyes, stating that we have only borrowed the world from our ancestors and this has to be given to the future generations at least as it is if not better. The sustainable development goals that have come into force after the MDGs clearly portray that long term goals need complete overhaul and can be satisfying only when nature and various natural resources are cherished, saved and conserved well. Various criteria about health and wellbeing can materialise only when the importance of environment, forests and trees is highlighted and their role is acknowledged. The sustainable development goals also mention about forests. In our analysis, we account for forests cover (expanse of forest in a country or a region) of states as synonymous to their vision of economic development with sustainability parameters.

Study of the relation between the role of social forestry and sustainable development highlighted that investments in forestry and tree growing will have to be enormous in the medium-term future to achieve a reasonable balance between requirements for environmental stability and local demands for forest and tree products. (Gregersen; Draper and Ela, 1989). Their findings of a study employing a panel data model for 130 countries, suggested evidence of diminishing marginal propensity to emit $\mathrm{CO} 2$ as economies develop. Further, the forecast results indicate that global emissions of $\mathrm{CO} 2$ will continue to grow at an annual rate of 1.8per cent. (Holtz-Eakin and Selden ,1995). A study highlighted the assessment of socio-economic and biophysical constraints on the deforestation process and quantified forest change hotspots by utilizing land use/cover data, in conjunction with socio-economic and biophysical indicators of South India. Jayantha Kumaran et al. (2012) using ARDL methodology compares the relationship between growth, trade and energy use for India and China. (Prasad and Badarinath, 2005). It was also proposed that structural breaks are endogenously determined for the period 1971-2007 using the Lagrange multiplier unit root test. (Lee and Strazicich, 2003). Another study put to light the issues concerning environmental sustainability and economic growth in India using micro and macro level evidences. They highlighted urbanization and forest cover change. The article stressed on existence of crucial environmental thresholds to India's growth strategy and various governance issues surrounding Indian environment policy to make growth more environmentally sustainable (Mukhopadhyay and Shyam Sundar, 2012). Another study investigated the dynamic causal relationships between $\mathrm{CO}^{2}$ emissions, economic growth, renewable and nonrenewable energy consumption, and trade in Tunisia during the period 1980-2009. The authors observe that EKC hypothesis is not supported in the long-run, whereas in the short-run the inverted Ushaped EKC hypothesis is supported. In case of trade, both per capita exports and imports 
have a positive impact on per capita $\mathrm{CO}^{2}$ emissions. (Jelbi and Youssef, 2015). Another study focused on study of state of Karnataka and analysed green GDP which would measure sustainability of development. It would be an appropriate and valuable decision-making aid in economic planning. (Singh et al., 2016). Also, study has been conducted to highlight the concept of the importance of sustainable development in Uttarakhand and suggests some important measures to improve sustainability. The relation between economic growth and sustainable development was also presented in the paper. (Singh and Nautiya, 2017)

\section{Materials and Methods}

Sources of data -Secondary data has been used in the analysis. The various sources for this data include the Envi Stats 2020 (Supplement on Environmental Accounts) and Indian Forest survey report 2019 and 2017, RBI report 2020.

Techniques and methods used-To compute the relationship between the sustainability parameter and the gross domestic state product, a number of techniques including - ratios, percentages, graphs and the statistical technique of correlation has been applied. The SPSS Software has been used for computation.

\section{Objective}

To study the relationship between the Sustainability aspect as measured by the forest cover in different states and the economic growth as measured by the gross state domestic product (GSDP at constant prices 2011-2012). The aim primarily is to understand whether the various Indian states are growing and developing in a sustainable manner or not. The aim is also to make out whether along with economic growth, sustainability in the form of increasing forest cover in various states is taking place or not. If it is increasing, what is its extent and what is the scope for improvement. To analyse the change in forest cover in different states over the five-year period, between 2015 and 2019. The hypothesis can be stated that the growth in GSDP and sustainable development go hand in hand for the various states. Indian states have started giving importance to sustainable development. The various assumptions made include that the GSDP of states is evenly distributed throughout the year, the gross state domestic product is assumed to increase at the same rate throughout the year as the data about forest cover is available yearly from January to December while the GSDP is available for the financial year April to March and weighted averages have been computed to find out the yearly GSDP for 2015-19. Forest cover is an important constituent to analyse the sustainability aspect.

\section{Discussion and Result}

Economic growth is measured using the quantitative measures and under this study the gross state domestic product (GSDP at constant prices 2011-2012) of various Indian states has been accounted for the years 2015-19. Economic growth is deemed narrower in approach to economic development which is considered a holistic approach that accounts for various indicators apart from income which aim at enhancing quality of life of people, provide selfesteem and freedom. it should be emphasized that development accounts for the concept of sustainability which is at its core.

The comparison between the gross state domestic product change from the year 201519 shows that every state has improved its GSDP ranging from 26.821 per cent to 47.721 percent between 2015-19. This shows that between the years, GSDP has improved considerably for all the Indian states under the study. Karnataka, Andhra Pradesh, Bihar, Telangana, Haryana, Sikkim, Tripura etc., show the highest percentage increase in GSDP from 2015- 19 and Bihar, Karnataka, Meghalaya, Telangana, Tripura etc., show increase between the time period 2017-2019. Though the overall aggregate score for all states shows a very 
positive and healthy sign as far as the increase is concerned, it ranks lower in comparison to the rest of the states for Meghalaya, Himachal Pradesh, Chhattisgarh, Rajasthan, West Bengal, Punjab (2015-2019) and Uttar Pradesh, Odisha, Punjab, West Bengal (2017-2019) etc.

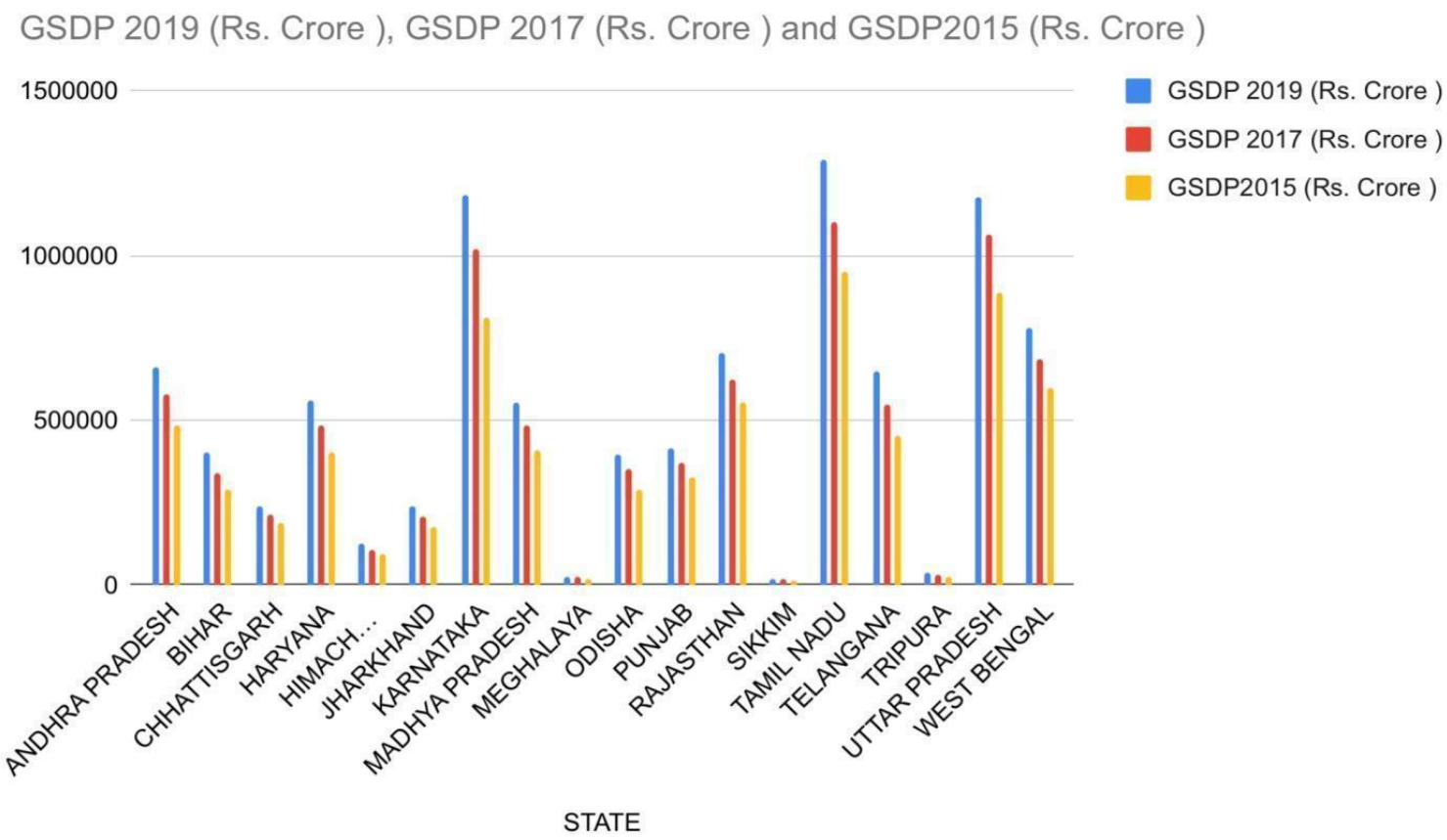

Figure 01: GSDP of Different Indian States a Comparative View (2015 to 2019)

Figure 1 depicts the GSDP (at constant price 2011-2012) for the year 2015- 2019 (Rs. crore). It clearly shows that states like Karnataka, Tamil Nadu, Uttar Pradesh, West Bengal, Andhra Pradesh etc., have high GSDP aggregates. Also, the figure clearly depicts that no state has registered negative growth in GSDP and every state has shown increase in its aggregate buy a significant amount.

Figure 2 has also been prepared showing the percentage increase in GSDP of the various states highlighting the trend of considerable increase in GSDP. This shows that all states have fared well on the GSDP percentage increase criteria. The period under study has seen commendable increase showing how the states have been the path of continuous growth over the time period under study. Figure 2 depict the percentage change in GSDP from 201519. This clearly states that the eastern street of Tripura has shown the highest percentage increase between the GSDP during the two time periods. Other states that have shown considerable improvement include the southern state of Karnataka, its neighbouring state of Telangana, Odisha, Haryana, Bihar and Tamil Nadu. On the other hand, the states that have shown lower percentage increase the ones where the percentage change ranges from 20 to 30 per cent. These include the states of Chhattisgarh, Meghalaya, Punjab, Rajasthan and West Bengal.

In figure 3, the percentage change in forest cover between 2015 to 2019 clearly highlights that Andhra Pradesh has made significant leap in increasing its forest cover over the period. There is massive difference between the high-ranking state of Andhra Pradesh and second in rank Karnataka. Apart from Karnataka certain states including Himachal Pradesh, Punjab, Rajasthan, Telangana etc., have also shown improvement. But certain states including Meghalaya, Sikkim, and Tripura Have shown negative growth rate. But the 
fact still remains that these eastern states have a huge percentage of their total area covered under forest.

\section{Percentage change in GSDP $2017-2019$ v STATE}

25

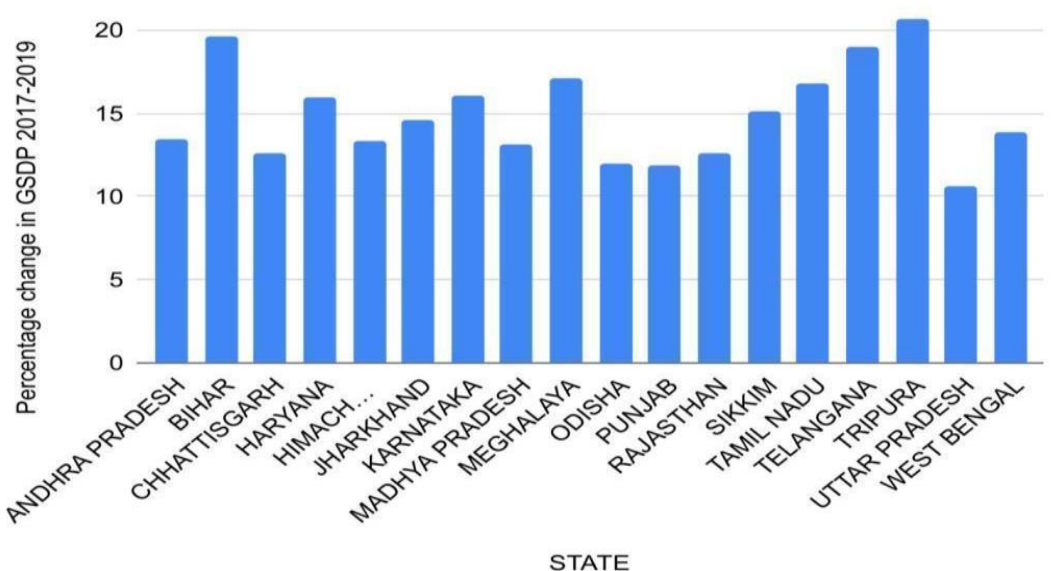

Percentage change in GSDP 2017-2019

Figure 02: Percentage Change in GSDP from 2015-19

2019percentage forest area(out of total area of state) 2019, 2017percentage forest area(out of total area of state) 2017 and 2015percentage forest area(out of total area of state) 2015

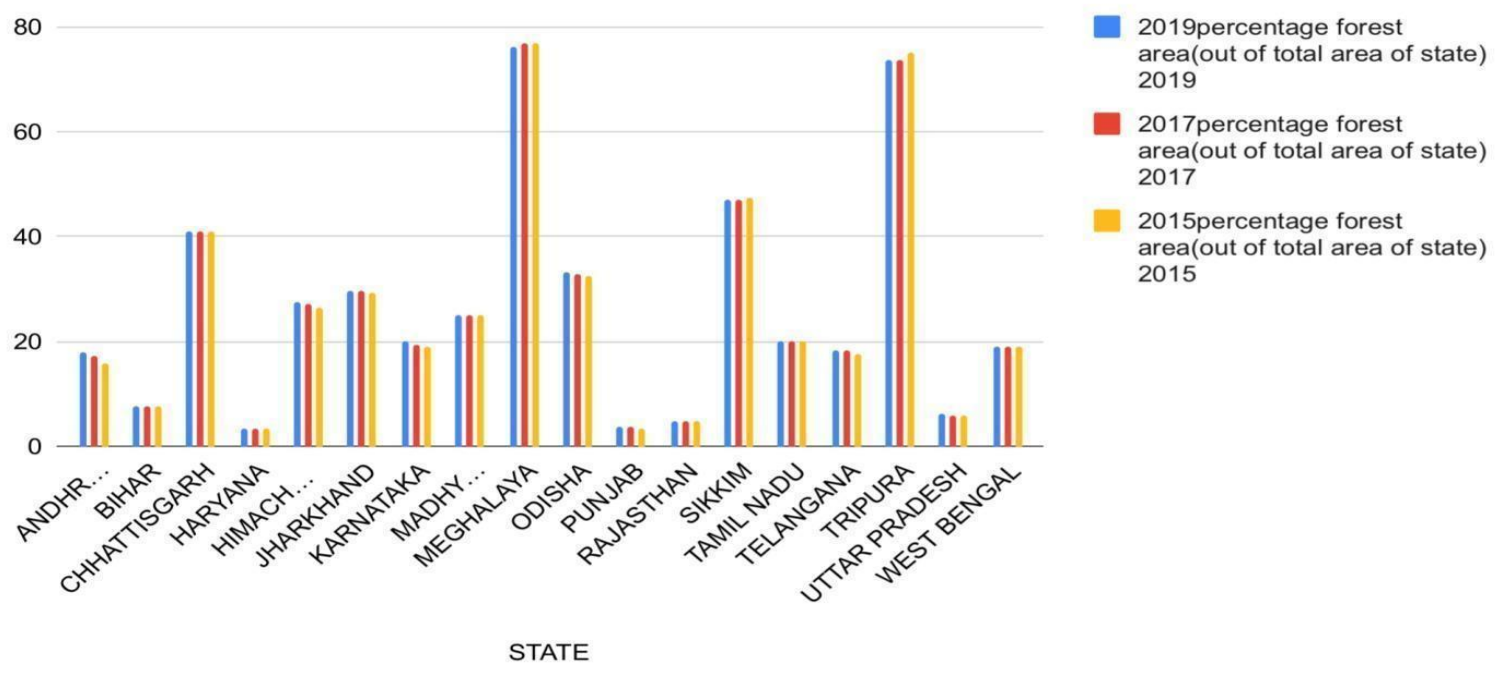

Figure 03: Percentage Area Under Forest Cover of Indian states for 2015-19

Figure 4 takes into consideration the change in forest area between 2015 to 2019 and its relationship with the percentage of forest area in the year 2019. The first one clearly shows that Andhra Pradesh, Karnataka and Himachal Pradesh stand far ahead than the other states, which lie somewhere between negative growth to 1 per cent. These three states in 2019 have forest cover. The other states except Sikkim, Tripura and Meghalaya lie in a similar bracket and it can clearly be seen that these states have had lower share of forests initially and have shown little improvement over the years. Bihar, Punjab, Rajasthan, West Bengal, Uttar Pradesh, Haryana etc., fall in similar categories, all having low percentage area under forest cover signifying lack of sustainability approach in development and little efforts to improve the very same The figure showing the comparative analysis between percentage change in GDP from 2015 to 2019 accounting for the percentage change in forest area during the same period, it becomes clear that Andhra Pradesh has outshined all other Indian states understudy. Certain states including that of Meghalaya Sikkim and Tripura rank quite low in percentage change in forest cover from 2015 to 19, depicting negative growth rate, but very 
significantly in their GSDP ranking. Tripura his outshined all other Indian states In terms of increase in GSDP during the period under study, followed by Karnataka and Telangana. Accounting for the percentage change in forest area The top-ranking state of Andhra Pradesh is followed by its neighbouring state of Karnataka. Karnataka can be seen as an apt example of how it has improved both its GSDP percentage over the years and has also significantly shown improvement in the increase in forest area between the four years period under study. But a large number of states other than these lie in a similar bracket of 25 to 40 per cent in percentage change in GSDP between 0 per cent to 5 per cent change in forest area between the same time period.

percentage change from 2015 to 2019 v STATE

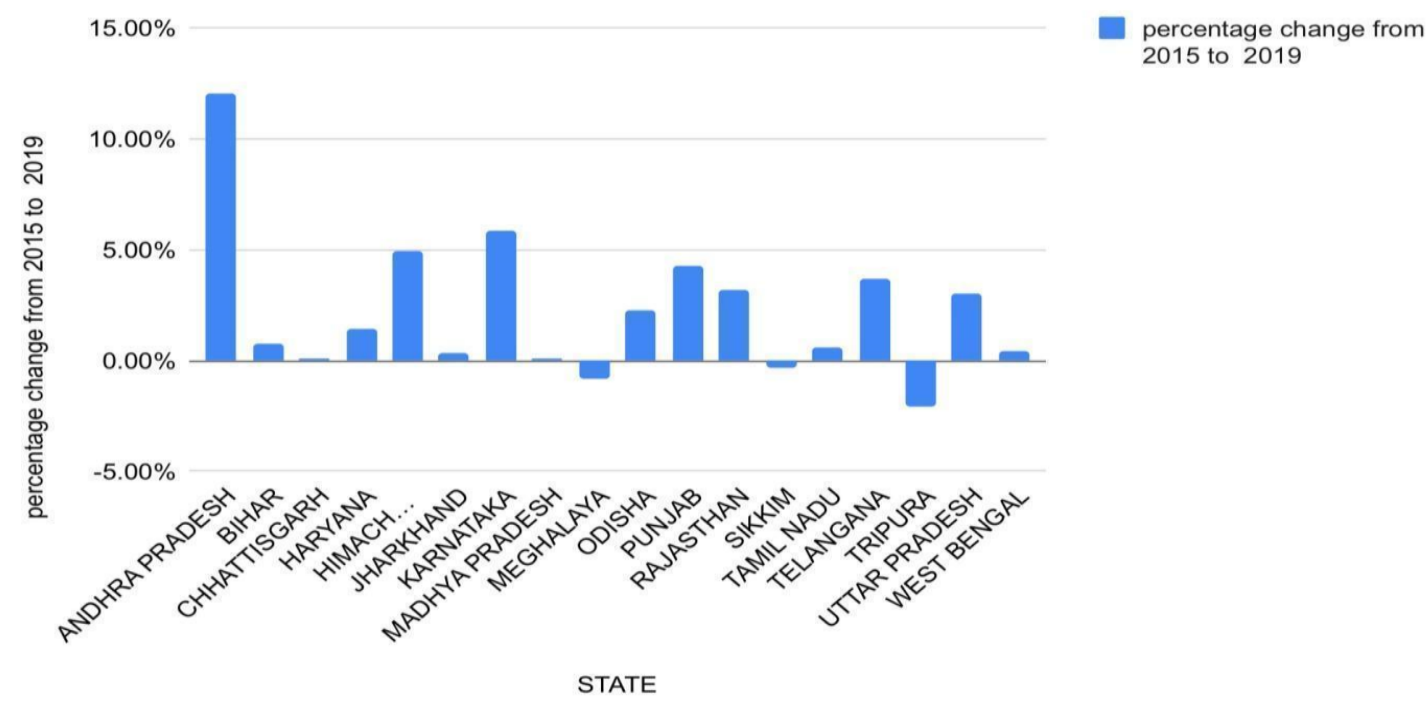

Figure 04: Percentage Change in Forest Cover between 2015 to 2019

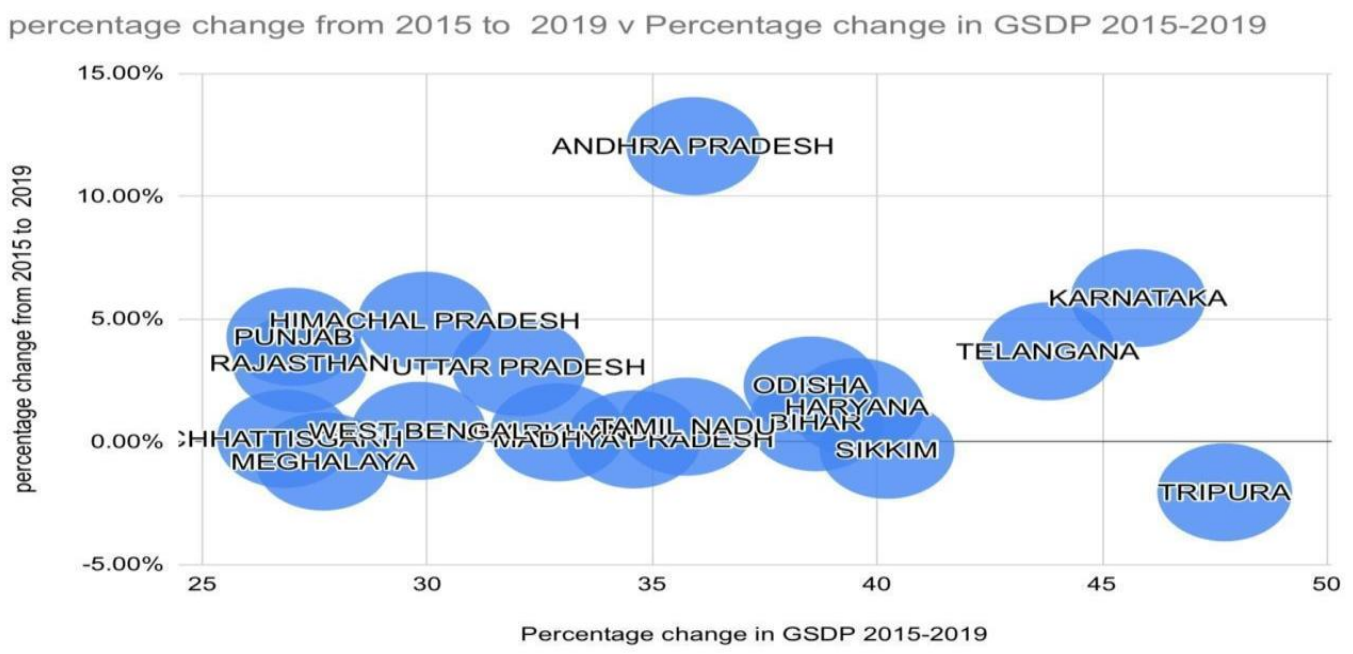

Figure 05: Relationship of percentage change of GSDP and percentage change of forest cover (2015-2019)

The major chunk of states in India lie in a similar bracket where the GSDP growth rate ranges between 20 per cent -30 per cent while a minute change in forest cover, showing sustainable development negligence. The major chunk of percentage increase lies in a bracket lower than 0.01 percent. Examples of such states include Bihar, Telangana, Haryana, West Bengal, Tamil Nadu, Jharkhand, Rajasthan Orissa, Chhattisgarh etc. Meghalaya is an exception hair which has performed poorly on both grounds, the GSDP front and the 
sustainability front. But a sign of caution here is that the state has one of the maximum areas under forest cover. On the other hand, there are only three states as mentioned above which have done an applaudable job via-a-vis all other states. This shows that these states have a long-term vision of growth along with sustainability.

\section{Limitations}

Nineteen states have been accounted for the analysis, for which the secondary data was available. Certain states and union territories have been excluded because the latest GSDP data was not available on the government website for the same. Secondary data from government sources has been has been used in regards to the total forest cover. The possibility of qualitative deterioration of this forest has been ignored.

\section{Conclusion}

Thus, it is clear that a majority of Indian states fall in the similar category. Only few states, namely, Andhra Pradesh, Himachal Pradesh and Karnataka have shown satisfactory improvement. All other states lie on similar footing where under they have followed a shortterm Growth approach, notwithstanding the fact that sustainability holds the key. The silver lining is the fact that sustainability as a concept has emerged as the forest area has not reduced, even when it has increased only minutely but a long road still needs to be taken. It is time that states realize that development is not a narrow concept, and human beings are only a very small element in the endless world. It is in the best interest of all to understand that man can survive only when it stays in harmony and not at war with nature. We need to broaden our horizons and understand that real development can only come with the approach of sustainability deep-rooted in it.

\section{References}

1. Acemoglu, D., Johnson, S. \& Robinson, J. A. (2001). The colonial origins of comparative development: An empirical investigation. The American Economic Review 91, 1369-1401.

2. Chauhan, Pradeep S. (2019). Climate Change and Paris Agreement: Challenges after US Withdrawal. New Century Publications, New Delhi.

3. Chauhan, P. (2009). Energy and Climate Change: Issues of Sustainable Development. Associate Publisher.

4. Chauhan, P.S. (2010). Energy and Sustainable Development. Trafford Publication: USA.

5. Chauhan, P.S. (2014). Energy and Sustainable Development in India. Twenty first Century: PB

6. Carroll, M., Townshend, J. R. G. \& Hansen, M. C. MODIS Vegetative Cover Conversion and Vegetation Continuous Fields. In Land Remote Sensing.

7. Dr. P.D. Singh, Dr. Sunita Gusainv and Prof. R.R. Nautiya (2017). Growth of SDP and structural changes in state economies: interstate comparison. Researcher 2017;9(11). Also please refer to the document at http://www.sciencepub.net/researcher.

8. EnviStats 2019

9. Gregersen, H; Draper, S; Ela, D (1989). People and trees: The role of social forestry in sustainable development. Publication Date:1989-01-01 Research Org.: International Bank for Reconstruction and Development, Washington, DC (USA). Economic Development Inst.

10. Grossman, G. M. \& Krueger, A. B. (1995). Economic Growth and the Environment. The Quarterly Journal of Economics 110, 353-377.

11. Handbook of Statistics On Indian States \{Gross State Domestic Product (constant prices), $\mathrm{RBI}$

12. Hansen, B. (2000). Sample splitting and threshold estimation. Econometrical 68, 575-603. 
13. Holtz-Eakin, D. and Selden, T.M. (1995). Stoking the fires? CO2 emissions and economic growth. Journal of Public Economics, Vol. 57, pp. 85-101

14. Hosonuma, N. et al. An assessment of deforestation and forest degradation drivers in developing countries. Environmental Research Letters 7, 044009 (2012).

15. Kauppi, P. E. et al. (2006). Returning forests analyzed with the forest identity. Proceedings of The National Academy of Sciences 103, 17574-17579.

16. Indian state of Forest report (2019). Published by - Forest survey of India (Ministry of environment Forest and climate change), Dehradun, Uttarakhand.

17. Jayanthakumaran, K., Verma, R. and Liu, Y. (2012). CO2 emissions, energy consumption, trade and income: a comparative analysis of China and India. Energy Policy, No. 42, pp. 450-460.

18. Jayachandran, S. (2013). Liquidity constraints and deforestation: The limitations of payments for ecosystem services. The American Economic Review: Papers \& Proceedings 103, 309-313.

19. Jebli, M.B. and Youssef, S.B. (2015). The Environmental Kuznets Curve, economic growth, renewable and non-renewable energy, and trade in Tunisia. Renewable and Sustainable Energy Reviews, Vol. 47, pp. 173-185.

20. Kaya, Y. and Yokobori, K. (1993). Environment, Energy and Economy: Strategies for Sustainability. BROOK-0356/XAB, United Nations University Press, Tokyo.

21. Lee, J. and Strazicich, M.C. (2003). Minimum Lagrange multiplier unit root test with two structural breaks. Review of Economics and Statistics, Vol. 85 No. 4, pp. 1082-1089.

22. Mukhopadhyay, P. and Shyamsundar, P, (2012). Economic growth and ecological sustainability in India. The Oxford handbook of Indian economy.

23. O'Grady, M. A., Eiras, A. I., Schaefer, B. D. \& Kim, A. B. Index of economic freedom. Heritage Foundation (2006).

24. Östlund, L., Zackrisson, O. \& Axelsson, A. L. (1997). The history and transformation of a Scandinavian boreal forest landscape since the 19th century. Canadian Journal of Forest Research 27, 1198-1206.

25. Prasad V, Badarinath (2005). Assessing forest cover sustainability and deforestation risk from social economic and biophysical indicators - a case study from Ramapa forests. $\begin{array}{lllll}\text { South India. } & \text { First } & \text { published: } & & \end{array}$ https://doi.org/10.1002/sd.250

26. Pao, H.-T. and Tsai, C.-M. (2011). Modeling and forecasting the $\mathrm{CO} 2$ emissions, energy consumption, and economic growth in Brazil. Energy, Vol. 36, pp. 2450-2458.

27. Singh R, Soujanya N, Singh V, Keshava RS, Kumar, Kakkar R (2016). Green GSDP for sustainable development. Chapter First Online: 16 November 2016 Part of the Environmental Challenges and Solutions book series (ECAS, volume 3).

28. Redo, D. J., Grau, H. R., Aide, T. M. \& Clark, M. L. (2012). Asymmetric forest transition driven by the interaction of socioeconomic development and environmental heterogeneity in Central America. Proceedings of the National Academy of Sciences 109, 8839-8844.

29. Zaloumis, N. P. \& Bond, W. J. (2016). Reforestation or conservation? The attributes of old growth grasslands in South Africa. Philosophical Transactions of the Royal Society B 371, 20150310

30. World Bank. World Development Indicators data.worldbank.org (2010).

31. www.niti.gov.in

32. www.mospi.gov.in

33. www.un.org 


\section{APPENDICES}

Appendix 01: shows the percentage forest area for the years 2015, 2017 and 2019 and also the percentage change in forest area from 2017 to 2019 and from 2015 to 2019.

\begin{tabular}{|l|c|c|c|c|c|}
\hline State & $\begin{array}{c}\text { GSDP 2019 } \\
\text { (Rs. Crore) }\end{array}$ & $\begin{array}{c}\text { GSDP 2017 } \\
\text { (Rs. Crore) }\end{array}$ & $\begin{array}{c}\text { GSDP 2015 } \\
\text { (Rs. Crore) }\end{array}$ & $\begin{array}{c}\text { Percentage } \\
\text { change in GSDP } \\
\text { 2015-2019 }\end{array}$ & $\begin{array}{c}\text { Percentage } \\
\text { change in GSDP } \\
\text { 2017-2019 }\end{array}$ \\
\hline Andhra Pradesh & 659339.02 & 581183.535 & 485095.76 & 35.91935333 & 13.44764266 \\
\hline Bihar & 405145.395 & 338579.45 & 292236.74 & 38.63602331 & 19.66036184 \\
\hline Chhattisgarh & 240403.1225 & 213438.9825 & 189561.04 & 26.82095567 & 12.63318429 \\
\hline Haryana & 561951.0725 & 484715.86 & 402687.22 & 39.55026248 & 15.93412118 \\
\hline Himachal Pradesh & 122765.0525 & 108289.1975 & 94470.59 & 29.95055128 & 13.36777383 \\
\hline Jharkhand & 236273.6325 & 206233.955 & 177794.46 & 32.89144808 & 14.56582525 \\
\hline Karnataka & 1181879.175 & 1018205.29 & 810604.71 & 45.80215985 & 16.07474314 \\
\hline Madhya Pradesh & 551853.4475 & 487804.6275 & 410037.92 & 34.58595427 & 13.13001484 \\
\hline Meghalaya & 26191.9125 & 22355.805 & 20513.89 & 27.67891658 & 17.15933513 \\
\hline Odisha & 397341.9775 & 354912.2375 & 286838.03 & 38.52485931 & 11.95499493 \\
\hline Punjab & 413568.39 & 369608.8275 & 325570.28 & 27.0289137 & 11.89353696 \\
\hline Rajasthan & 703077.145 & 624274.97 & 552881.88 & 27.16588668 & 12.62299128 \\
\hline Sikkim & 19693.4675 & 17104.3375 & 14044.86 & 40.21832542 & 15.13727147 \\
\hline Tamil Nadu & 1288523.775 & 1103535.61 & 949150.61 & 35.75545982 & 16.7632257 \\
\hline Telangana & 650650.4025 & 546605.18 & 452489.84 & 43.7933728 & 19.0348036 \\
\hline Tripura & 39635.8175 & 32848.7825 & 26831.47 & 47.72137904 & 20.66145069 \\
\hline Uttar Pradesh & 1174824.7 & 1061661.948 & 889789.06 & 32.03406884 & 10.65901931 \\
\hline West Bengal & 779798.59 & 684589.2225 & 600749.58 & 29.8042672 & 13.9075177 \\
\hline
\end{tabular}

Appendix 02: shows GSDP (Rs. Crore) of various Indian states and union territories under study for the years 2015, 2017 and 2019 and also the percentage change in GSDP from 2017 to

\begin{tabular}{|l|c|c|c|c|c|}
\hline & $\begin{array}{l}\text { Percentage } \\
\text { forest area (out } \\
\text { of total area of } \\
\text { state) 2019 }\end{array}$ & $\begin{array}{l}\text { Percentage } \\
\text { forest area (out } \\
\text { of total area of } \\
\text { state) 2017 }\end{array}$ & $\begin{array}{l}\text { Percentage } \\
\text { forest area (out } \\
\text { of total area of } \\
\text { state) 2015 }\end{array}$ & $\begin{array}{l}\text { Percentage } \\
\text { change from } \\
\text { 2017 to 2019 }\end{array}$ & $\begin{array}{l}\text { Percentage } \\
\text { change from } \\
\text { 2015 to 2019 }\end{array}$ \\
\hline State & 17.88 & 17.27 & 15.96 & 3.53 & 12.03 \\
\hline Andhra Pradesh & 7.76 & 7.75 & 7.7 & 0.13 & 0.78 \\
\hline Chhar & 41.13 & 41.08 & 41.09 & 0.12 & 0.10 \\
\hline Haryana & 3.62 & 3.59 & 3.57 & 0.84 & 1.40 \\
\hline Himachal Pradesh & 27.72 & 27.12 & 26.42 & 2.21 & 4.92 \\
\hline Jharkhand & 29.62 & 29.54 & 29.51 & 0.27 & 0.37 \\
\hline Karnataka & 20.11 & 19.58 & 19 & 2.71 & 5.84 \\
\hline Madhya Pradesh & 25.14 & 25.11 & 25.12 & 0.12 & 0.08 \\
\hline Meghalaya & 76.33 & 76.79 & 76.96 & -0.60 & -0.82 \\
\hline Odisha & 33.15 & 32.98 & 32.41 & 0.52 & 2.28 \\
\hline Punjab & 3.67 & 3.65 & 3.52 & 0.55 & 4.26 \\
\hline Rajasthan & 4.86 & 4.84 & 4.71 & 0.41 & 3.18 \\
\hline Sikkim & 47.1 & 47.13 & 47.26 & -0.06 & -0.34 \\
\hline Tamil Nadu & 20.27 & 20.2 & 20.15 & 0.35 & 0.60 \\
\hline Telangana & 18.36 & 18.22 & 17.71 & 0.77 & 3.67 \\
\hline Tripura & 73.68 & 73.68 & 75.24 & 0.00 & -2.07 \\
\hline Uttar Pradesh & 6.15 & 6.09 & 5.97 & 0.99 & 3.02 \\
\hline West Bengal & 19.04 & 18.98 & 18.958 & 0.32 & 0.43 \\
\hline
\end{tabular}

